\title{
Effect of cerium on growth, dry matter production, biochemical constituents and enzymatic activities of cowpea plants [Vigna unguiculata (L.) Walp.]
}

\author{
R. Shyam and N.C. Aery* \\ Laboratory of Geobotany and Biogeochemistry, Department of Botany, University College of Science, Mohanlal \\ Sukhadia University, Udaipur-313001 (Rajasthan) India *Correspondingauthor: ncaery@yahoo.com
}

\begin{abstract}
A pot culture experiment was conducted to study the effect of various concentrations of cerium provided as cerium nitrate $(0.713,3.568,17.841,89.206$ and $446.030 \mu \mathrm{M})$ on the growth performance, dry matter production, biochemical constituents and enzymatic activity of cowpea plants [Vigna unguiculata (L.) Walp.]. Low concentrations of cerium were observed to be beneficial for the test plants. A positive correlation was observed between a lower level of cerium $(0.713-17.841 \mu \mathrm{M})$ and foliar chlorophyll content, relative yield (dry matter) and nitrate reductase activity. Higher levels of cerium (89.206-446.030 $\mu \mathrm{M})$ significantly increased the proline content and polyphenol oxidase activity of the test plants. Root growth was more adversely affected than shoot growth.
\end{abstract}

Keywords: Cerium; enzymatic activity; foliar chlorophyll content; free proline content; Vigna unguiculata (L.) Walp.

Abbreviations: NR, Nitrate reductase; NiR, Nitrite reductase; PPO, Polyphenol oxidase; REEs, Rare earth elements; ROS, Reactive oxygen species. 


\section{Introduction}

Of the 92 elements present in the earth's crust, only 17 elements are known to be essential to all plants, and 12 elements have been proven to be potentially beneficial in trace amounts. These include Silver (Ag), Cerium (Ce), Chromium (Cr), Fluoride (F), Iodine (I), Lanthanum (La), Rubidium (Rb), Tin ( $\mathrm{Sn})$, Strontium (Sr), Titanium (Ti), Vanadium (V) and Tungsten (W) (Pilon-Smits et al., 2009).

Lanthanum and cerium belong to the group of light rare earth elements (REEs) because their atomic mass is lower than $153 \mathrm{amu}$. These elements are fairly abundant in nature and beneficial for plant growth (Yin et al., 2009). Chloride and the nitrate forms of lanthanum and cerium are the main constituents of commercial REEs micro-fertilisers, and they have been widely used in China since the 1970s as REEs micro-fertilisers to improve crop plant growth and yield (Hu et al., 2004).

There are conflicting results regarding the effects of REEs on plant growth and development, most likely due to the effects of factors such as soil $\mathrm{pH}$, soil chelates and the available level of fertilisers. He and Loh (2000) reported that cerium provided as cerium nitrate $\left(0.5-10 \mu \mathrm{mol} \mathrm{L}^{-1}\right)$ in a culture medium significantly enhanced the primary root growth of Arabidopsis thaliana. However, REEs as (REE) $\mathrm{O}_{\mathrm{y}}$ decreased root length in rice plants (Hu and Ye, 1996). REEs enhanced the speed of seed germination and growth (shoot-root length) of agricultural crops such as rice, wheat, barley and vegetable crops (Guo et al., 1988; Ni, 1995; Shyam and Aery, 2011). A general requirement by crop plants for lanthanum and cerium has not yet been established.

With these facts in mind, cerium as cerium nitrate was applied to cowpea plants [Vigna unguiculata (L.) Walp.], an important leguminous agricultural crop grown in silty sand, to evaluate the effect of cerium on plant growth, dry matter production, biochemical constituents and enzymatic activities.

\section{Material and methods}

Cerium as cerium nitrate $\left[\mathrm{Ce}\left(\mathrm{NO}_{3}\right)_{3} \cdot 6 \mathrm{H}_{2} \mathrm{O}\right]$ was applied at doses of 0.713, 3.568, 17.841, 89.206 and $446.030 \mu \mathrm{M}$. The different concentrations of cerium were prepared separately by taking corresponding amounts (calculated based on molecular weight) of the chemical $/ \mathrm{kg}$ of air-dried soil. Pots without added cerium constituted the control. Three kilograms of soil were filled into earthen pots of $30 \mathrm{~cm}$ height and $25 \mathrm{~cm}$ diameter. The soil used was silty sand. The experiments were set up during the month of July under natural conditions. The maximum and minimum temperatures during the study period were $31.1^{\circ} \mathrm{C}$ and $24.5^{\circ} \mathrm{C}$, respectively, and the photoperiod was $12 \mathrm{hrs}$ Fifteen certified seeds of Vigna unguiculata (L.) Walp. Var. Sephali Sikha-313 were sown equidistantly at a 2 -cm depth in each replicate. Watering was performed on alternate days, with $200 \mathrm{ml}$ of water added to each pot. After establishment, the seedlings were thinned to 10 in each replicate. The sets were prepared in triplicate to record observations during the life stage.

\subsection{Statistical analysis}

The standard procedures suggested by Fisher (1950) were employed by applying the analysis of variance ratio (F) technique for "Complete Randomised Block Design" to test the significance of the experimental results (Table 1 and 2). In most cases, the $\mathrm{F}$ values were found to be highly significant. Critical differences (CD) for the treatment means were calculated at a 5\% 
and $1 \%$ level of significance. Table 1 and 2 summarises the effects, along with the $\mathrm{LSD} \pm$ and $\mathrm{CD}$ and their analysis of variance (ANOVA), and the correlation coefficient (r) and regression equations (y) were calculated as described by Panse and Sukhatme (1995).

\subsection{Measurement of growth and dry weight}

After flowering, the cowpea plants were harvested and washed with double distilled water, and the shoot-root length was measured. The plant samples were dried at $80^{\circ} \mathrm{C}$ for 48 hours in an oven and weighed to obtain the dry weight of the shoot and roots.

\subsection{Estimation of Foliar Chl. ' $a$ ', Chl. 'b' and total chlorophyll}

The foliar Chl.'a', Chl. 'b' and total chlorophyll were determined using the Arnon method (1949).

\subsection{Determination of free proline contents}

The free proline contents of the cowpea leaves were determined according to Bates et al. (1973) using the ninhydrin method. The fresh cowpea leaves $(0.5 \mathrm{~g})$ were hand-homogenised in $10 \mathrm{ml}$ of $3 \%(\mathrm{w} / \mathrm{v})$ sulfosalicylic acid. The homogenate was filtered through Whatman No. 2 filter paper. In another test tube, $2 \mathrm{ml}$ of acid ninhydrin and $2 \mathrm{ml}$ of glacial acetic acid were added to $2 \mathrm{ml}$ of the filtrated extract. The resulting mixture was incubated at $100^{\circ} \mathrm{C}$ in a hot water bath. The reaction was then stopped using an ice bath, and the contents were extracted with $4 \mathrm{ml}$ of toluene and mixed vigorously using a test tube stirrer for 15-20 seconds. The chromophore containing toluene was aspirated from the aqueous phase and thawed to room temperature, and the absorbance of the solution was measured at $520 \mathrm{~nm}$ using a UV-visible spectrophotometer (PHARMASPEC UV 1700, SHIMADZU). A mixture without the leaf sample was used as the blank. The proline concentration was determined from a standard curve prepared with L-proline. The results are expressed (free proline content) as $\mu$ moles of proline $\mathrm{g}^{-1}$ of fresh weight.

\subsection{Estimation of polyphenol oxidase (PPO) activity}

The polyphenol oxidase activity was measured according to the method described in Mahadevan and Sridhar (1982).

Enzyme assay

Fresh leaf samples $(0.05 \mathrm{~g})$ were homogenised in 0.1 $\mathrm{M}$ phosphate buffer (10 ml), $\mathrm{pH} 6.0$, and the homogenate was centrifuged for 30 minutes at $2000 \mathrm{~g}$ at $4^{\circ} \mathrm{C}$. The supernatant was used as the enzyme source. The enzyme activity in each extract was assayed in triplicate. Three $\mathrm{ml}$ of catechol $(0.1 \mathrm{M})$ were placed in a clean, dry cuvette that was transferred to a UV-visible spectrophotometer (PHARMASPEC UV 1700, SHIMADZU). To start the reaction, $0.1 \mathrm{ml}$ of supernatant was added to the cuvette. The initial absorbance and the subsequent changes in absorbance after each 30-second interval for 3 minutes at $495 \mathrm{~nm}$ were noted. A blank without supernatant was run simultaneously. The PPO activity was expressed as the change in absorbance/min/g fresh weight of leaf.

\subsection{Estimation of Nitrate reductase (NR) activity}

The NR activity was assayed according to Malik and Singh (1980). 


\section{Enzyme assay}

Fresh cowpea leaves $(0.2 \mathrm{~g})$ were cut into slices. The chopped plant leaves were suspended in $5 \mathrm{ml}$ of assay mixture. The assay mixture contained $4 \mathrm{ml}$ of $0.1 \mathrm{M}$ phosphate buffer ( $\mathrm{pH} 7.0$ ), $0.5 \mathrm{ml}$ of $0.1 \mathrm{M} \mathrm{KNO}_{3}$ and $0.5 \mathrm{ml}$ of $5 \% \mathrm{n}$-propanol. After capping, the test tube containing the assay mixture and plant tissue was incubated in the dark at $30^{\circ} \mathrm{C}$ for one hour in a cooling incubator (REMI-CI-10S). A blank without the leaf sample was also run simultaneously. After incubation, a 0.4-ml aliquot of the reaction mixture was removed and transferred into another test tube containing $1 \mathrm{ml}$ of $1 \%$ sulphanilamide (prepared in $1 \mathrm{~N} \mathrm{HCl}$ ) followed by $1 \mathrm{ml}$ of $0.02 \%$ NEDH (2-Napthylene diamine hydrochloride). After 20 minutes, $4 \mathrm{ml}$ of distilled water was added to each test tube. After 10 minutes, the absorbance was measured at $540 \mathrm{~nm}$ using a UV-visible spectrophotometer (PHARMASPEC UV 1700, SHIMADZU).

\section{Results and Discussion}

Cerium showed a positive effect on the shoot-root growth and relative yield (dry matter) and affected the biochemical constituents and enzymatic activity of the cowpeas [Vigna unguiculata (L.) Walp.].

The maximum enhancement in the foliar chlorophyll (Chl. 'a', Chl. 'b', Total Chl.) contents was observed at the $17.841 \mu \mathrm{M}$ concentration of cerium (Table 1 and Figure 1). The increase in chlorophyll ' $\mathrm{a}$ ' (Chl. 'a'), chlorophyll 'b', (Chl. 'b') and total chlorophyll over the controls were $188.68 \%, 212.59 \%$ and $145.57 \%$, respectively.
In soybean seedlings, cerium provided as cerium chloride $(20 \mathrm{mg} / \mathrm{L})$ enhanced the rate of photosynthesis and the chlorophyll content in aquaculture experiments $(\mathrm{Li}$ et al., 2007). An increase in the chlorophyll a and b contents were observed in wheat leaves after the plants were treated with individual rare earth elements and a mixture of light rare earths (Jie et al., 1985).

An increase in the absorption of nitrogen and phosphorus, an induction in the synthesis of a precompound of chlorophyll formation and an enhancement in the chlorophyll contents of spinach have been observed (Liao et al., 1994). Perhaps REEs play an indirect role in chlorophyll formation because some REEs are catalysts or because $\mathrm{Ce}^{3+}$ could enter into the chloroplast and bind easily to chlorophyll, replacing $\mathrm{Mg}^{2+}$ and form Ce- chlorophyll (Hong et al., 2002). In $\mathrm{Mg}^{2+}$-deficient Hoagland media, cerium chloride increased the synthesis of organic nitrogen, protein and chlorophyll in spinach plants. An $84.31 \%$ increase in the chlorophyll content over the control was observed at a $15 \mu \mathrm{M} \mathrm{Ce}^{3+}$ level (Yin et al., 2009) in spinach plants.

Higher concentrations of $\mathrm{Ce}$ (89.206 and 446.030 $\mu \mathrm{M})$ resulted in a decrease in the chlorophyll (Chl. 'a', Chl. 'b', Total Chl.) contents over the control. Wang et al. (2007) have also observed that La and Ce reduce chlorophyll content in Hydrilla verticillata. The reduction in chlorophyll content (Table 1 and Figure 1) may be due to the formation of chlorophyllase, which is responsible for chlorophyll degradation (Mali and Aery, 2009), damage to the photosynthetic apparatus and disturbance of chlorophyll biosynthesis or its degradation caused by lipid peroxidation (Somashekaraiah, 1992). 
Table 1. Showing the effect of various concentrations of cerium provided as cerium nitrate on the chlorophyll contents (Chl.'a', Chl.'b' and Total Chl.), proline contents, NR activity and polyphenol oxidase activity of Vigna unguiculata (L.) Walp.

\begin{tabular}{|c|c|c|c|c|c|c|}
\hline $\begin{array}{l}\text { Cerium } \\
\text { Concentra- } \\
\text { tions } \\
(\mu \mathrm{M})\end{array}$ & $\begin{array}{l}\text { Chl. 'a' } \\
\left(\mathrm{mg} \mathrm{g}^{-1}\right)\end{array}$ & $\begin{array}{l}\text { Chl. 'b' } \\
\left(\mathrm{mg} \mathrm{g}^{-1}\right)\end{array}$ & $\begin{array}{l}\text { Total Chl. } \\
\left(\mathrm{mg} \mathrm{g}^{-1}\right)\end{array}$ & $\begin{array}{l}\text { Proline } \\
\text { content } \\
\left(\mu \text { moles } g^{-1}\right)\end{array}$ & $\begin{array}{l}\text { NR activity } \\
\left(\mu \text { moles } \mathrm{g}^{-1}\right)\end{array}$ & $\begin{array}{l}\text { PPO } \\
\text { activity }\end{array}$ \\
\hline 0.000 & $0.7716 \pm 0.031$ & $0.1469 \pm 0.006$ & $1.4659 \pm 0.059$ & $6.70 \pm 0.270$ & $1.30 \pm 0.052$ & $5.55 \pm 0.223$ \\
\hline 0.713 & $1.0825 \pm 0.049$ & $0.1590 \pm 0.007$ & $1.5432 \pm 0.069$ & $6.60 \pm 0.297$ & $1.50 \pm 0.067$ & $3.11 \pm 0.140$ \\
\hline 3.568 & $1.1626 \pm 0.035$ & $0.1794 \pm 0.005$ & $1.7124 \pm 0.051$ & $5.30 \pm 0.159$ & $1.60 \pm 0.048$ & $2.93 \pm 0.088$ \\
\hline 17.841 & $1.4559 \pm 0.025$ & $0.3123 \pm 0.005$ & $2.1340 \pm 0.037$ & $4.90 \pm 0.085$ & $1.80 \pm 0.031$ & $2.6 \pm 0.046$ \\
\hline 89.206 & $0.3834 \pm 0.007$ & $0.1334 \pm 0.003$ & $1.1873 \pm 0.022$ & $7.70 \pm 0.145$ & $1.20 \pm 0.023$ & $6.76 \pm 0.128$ \\
\hline 446.030 & $0.3120 \pm 0.006$ & $0.1031 \pm 0.002$ & $1.1750 \pm 0.022$ & $8.40 \pm 0.159$ & $1.00 \pm 0.019$ & $8.01 \pm 0.151$ \\
\hline LSD & 0.0156 & 0.0027 & 0.0256 & 0.1139 & 0.0239 & 0.0802 \\
\hline $\begin{array}{l}\mathrm{CD}(\mathrm{P}=0.05) \\
(\mathrm{CD} \text { at } 5 \%)\end{array}$ & 0.0481 & 0.0084 & 0.0789 & 0.3510 & 0.0737 & 0.2471 \\
\hline $\begin{array}{l}\mathrm{CD}(\mathrm{P}=0.01) \\
(\mathrm{CD} \text { at } 1 \%)\end{array}$ & 0.0674 & 0.0117 & 0.1107 & 0.4921 & 0.1033 & 0.3464 \\
\hline CV $(\%)$ & 3.14 & 2.73 & 2.89 & 2.99 & 2.96 & 2.87 \\
\hline $\begin{array}{l}\text { General } \\
\text { mean }\end{array}$ & 0.861 & 0.172 & 1.536 & 6.600 & 1.400 & 4.832 \\
\hline $\mathrm{r}$ & -0.6888 & -0.4937 & -0.5713 & 0.7305 & -0.7370 & 0.7707 \\
\hline$r^{2}$ & 0.4744 & 0.2437 & 0.3264 & 0.5337 & 0.5432 & 0.5939 \\
\hline$y=a+b x$ & $\begin{array}{l}1.02614 *- \\
0.00177 *^{x}\end{array}$ & $\begin{array}{l}0.19138 *- \\
0.00020 * \mathrm{x}\end{array}$ & $\begin{array}{l}1.64445^{*}- \\
0.00116^{*} \mathrm{x}\end{array}$ & $\begin{array}{l}6.08252 * *+ \\
0.00557 * \mathrm{x}\end{array}$ & $\begin{array}{l}1.51254 * \\
0.00121 *^{*}\end{array}$ & $\begin{array}{l}3.91004 * *+ \\
0.00992 * \mathrm{x}\end{array}$ \\
\hline
\end{tabular}

PPO activity unit: Change of Absorbance/minute/g fresh weight of leaf * = Significant at $5 \%$ level of significance.

** = Significant at $1 \%$ level of significance 


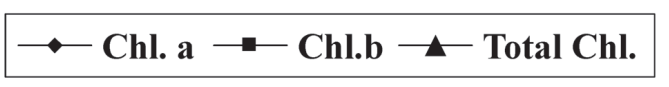

\section{Represent the SD value}

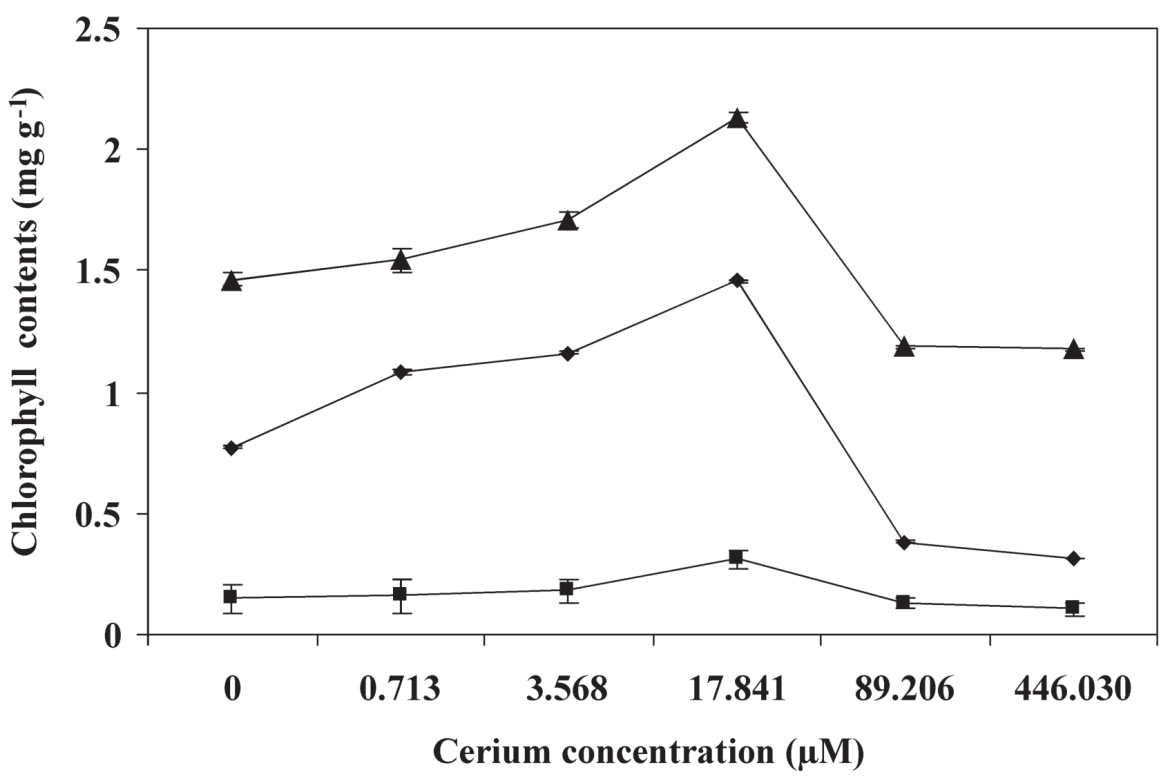

Figure 1. The effect of various concentrations of cerium on the chlorophyll contents of Vigna unguiculata (L.) Walp.

Proline (Pyrrolidin-2-carboxylic acid) is a five-carbon amino acid that is known to accumulate in plant tissues in response to salt, water and heavy-metal stress. The accumulation of proline by plants is an adaptive mechanism. Proline accumulation helps plants tolerate stress as the proline accumulates in the cytoplasm (Ketchum et al., 1991) where it functions as an osmotic buffer and an ROS-scavenger in addition to its function as osmo-protectant and membrane stabiliser. Lehoczky et al. (2000) proposed that proline also acts as a source of carbon and nitrogen for rapid recovery from the stress.

The maximum proline contents were observed at the $446.030 \mu \mathrm{M}$ level of cerium and were $25.37 \%$ higher than the control (Table 1 and Figure 2). The minimum proline content was observed at the $2.5 \mu \mathrm{g} \mathrm{g}^{-1}$ concentration of cerium and was $26.83 \%$ lower than the con- trol. An increased proline content at the higher cerium concentrations (89.206-446.030 $\mu \mathrm{M})$ might contribute to the involvement of proline in scavenging reactive oxygen species (ROS). This increase was significant at the $5 \%$ and the $1 \%$ level of significance. Li Guotai (2010) studied the effect of cerium on the chilling resistance of cucumber seedlings and showed that under chilling stress conditions, cerium increased the chlorophyll content and proline level in cucumbers. Toxic levels of $\mathrm{La}$ and $\mathrm{Ce}(30-100 \mu \mathrm{M})$ increased the free proline level of Hydrilla verticillata (Wang et al., 2007). REEs are also supposed to be involved in increasing the water use efficiency of plants by increasing their proline content. Proline has a strong ability for hydration. This indicates that an increased amount of proline may help plants to conserve water during drought periods (H. El-Ramady, 2008). 


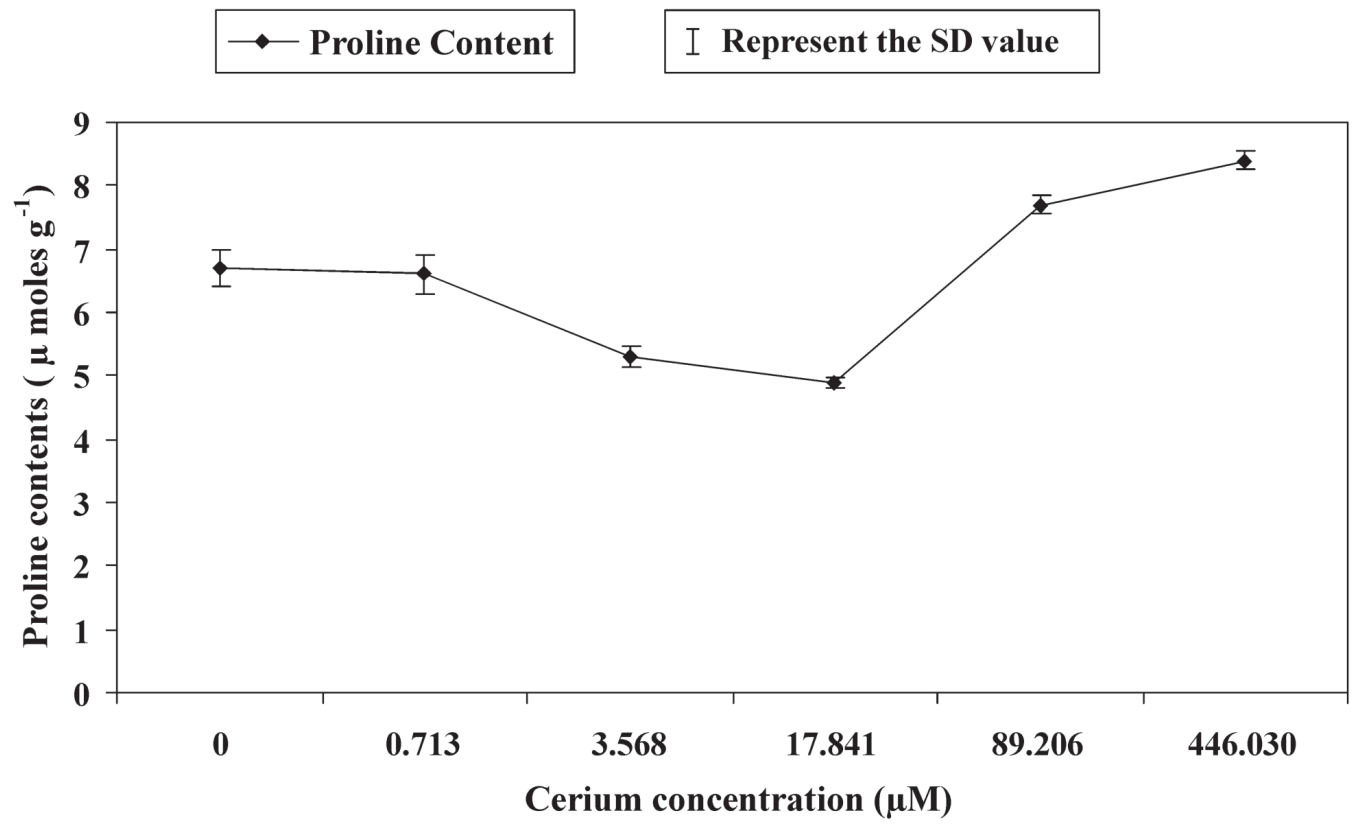

Figure 2. The effect of various concentrations of cerium on the free proline contents of Vigna unguiculata (L.) Walp.

NR is the key enzyme in nitrate metabolism and is important in providing the organic nitrogen that is essential for plant growth. The maximum increase $(38.46 \%)$ in the activity of NR over the control was observed at the $17.841 \mu \mathrm{M}$ concentration of cerium, and this increase was significant at the $5 \%$ and $1 \%$ level of significance. The minimum NR activity was observed at the $446.030 \mu \mathrm{M}$ level of cerium, which was $23.07 \%$ lower than the control (Table 1 and Figure 3). NR catalyses the reduction of nitrate to nitrite during the assimilation of nitrate by the plant cell. Nitrogenase converts nitrogen gas to ammonia in a nitrogen-fixing micro-organism. The reduction of nitrate to ammonium proceeds by the sequential ac- tion of the NR and NiR (Guerrero et al., 1984). NR, a molybdoflavo-protein, has Mo as a cofactor required for the transfer of electrons from $\mathrm{NADH}_{2}$ to nitrate. The source of the reductant is either the mitochondrial electron transport in the dark or the photosynthetically produced reductant in the light (Beevers and Hageman, 1969). Nitrate reductase is very sensitive to heavy metals because they have an affinity for sulfhydryl groups. The inhibition of NR activity at higher concentrations (89.206-446.030 $\mu \mathrm{M}$ ) of $\mathrm{Ce}^{3+}$ might be due to interference with the NR structure, either due to the replacement of Mo or by weak binding with the -SH groups, which often determine the secondary and tertiary structure of proteins (Awasthi, 2005). 


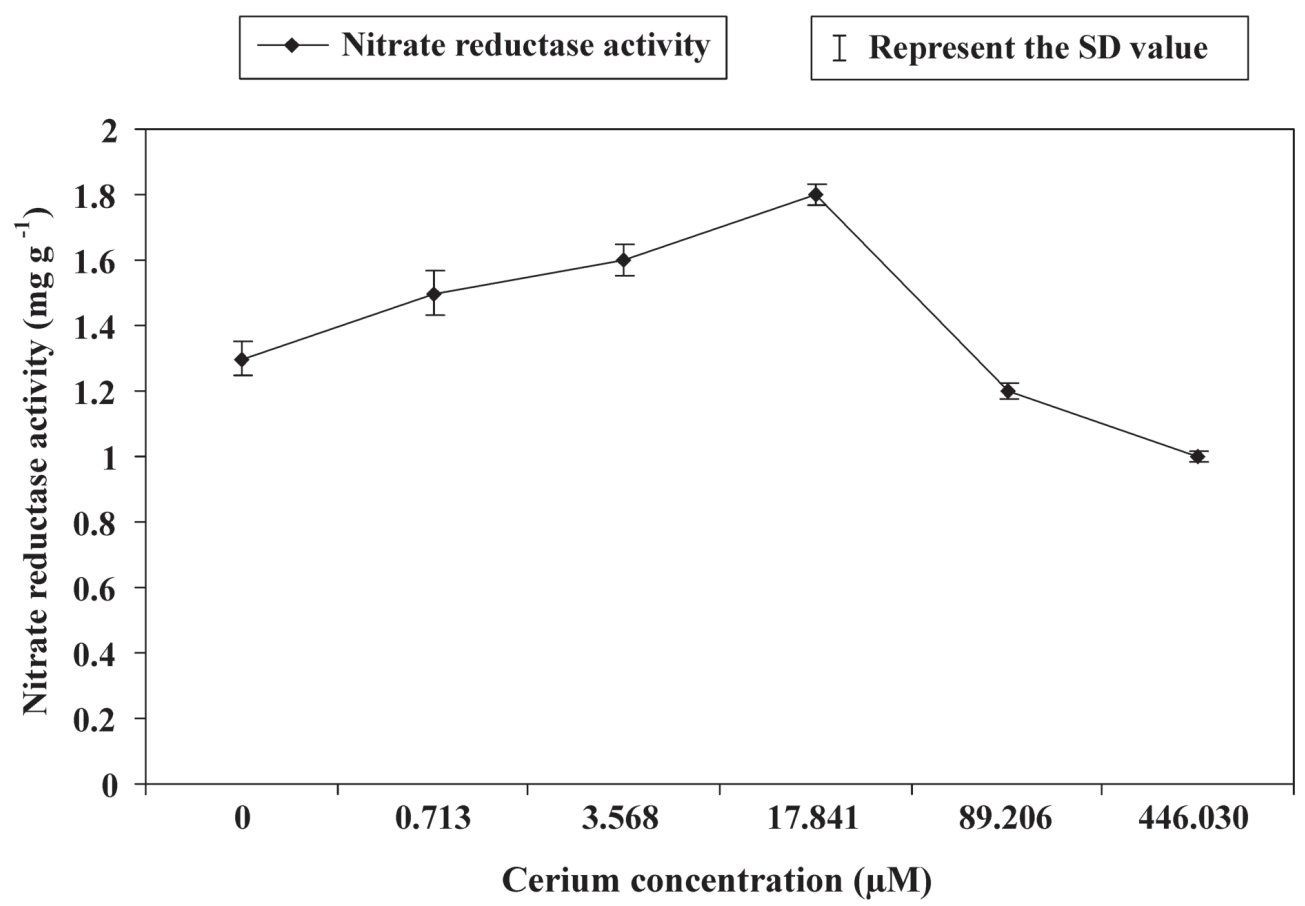

Figure 3. The effect of various concentrations of cerium on the activity of nitrate reductase enzyme in Vigna unguiculata (L.) Walp.

PPO is essentially a Cu-dependent enzyme (Del Rio, 1983) and is involved in the oxidation of phenolic compounds as well as in the biosynthesis of lignins. The oxidation of phenolic compounds led to the production of quinones. Quinones are responsible for the reduction of toxic oxygen species and are considered to be more toxic than the phenols from which they are derived (Pillinger et al., 1994).

In the present study, the PPO-activity was found to be at a minimum at the $17.841 \mu \mathrm{M}$ concentration of cerium and was $52.61 \%$ lower than the control, and the maximum increase $(44.32 \%$ higher than the control) in PPO activity was observed at the 446.030 $\mu \mathrm{M}$ level of cerium (Table 1 and Figure 4). An enhancement in the enzymatic activity was also observed at the $89.206 \mu \mathrm{M}$ level of cerium, which was $21.80 \%$ higher than the control. It is possible that the mechanism for increasing PPO activity occurs in a 'latent form' in plants. The increased activity of PPO in the plant tissue after metal stress could have resulted from the activation of 'latent phenolase' or from 'solubilising' phenolase from the cellular structure as reported by Robby et al. (1964) for diseased plants under pathogen stress or due to de novo synthesis of polyphenol oxidase under metal stress (Michalak, 2006). 


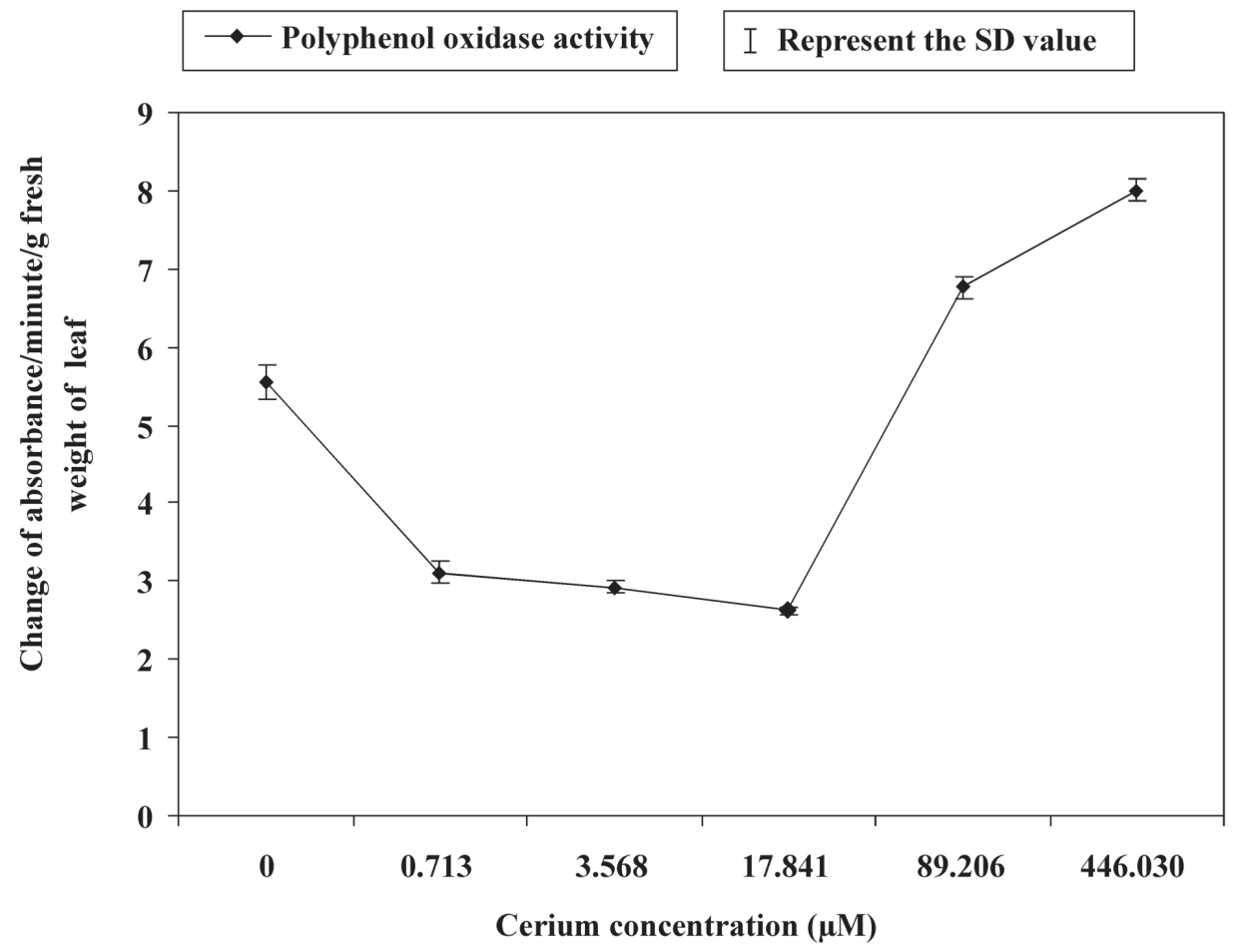

Figure 4. The effect of various concentrations of cerium on the activity of polyphenol oxidase enzyme in Vigna unguiculata (L.) Walp.

In a solution culture study, cerium as cerium nitrate $\left(0.5 \mu \mathrm{g} \mathrm{g}^{-1}\right)$ significantly increased the shoot-root growth $(14.99 \%$ and $47.44 \%)$ and relative yield $(153.75 \%$ and $266 \%)$ of wheat seedlings (Shyam and Aery, 2011). The results of the present study indicate that certain low concentrations (0.713-17.841 $\mu \mathrm{M})$ enhanced the growth (shoot-root length) and relative yield of cowpeas (Table 2 and Figure 5\&6). The maximum enhancement in shoot-root length and relative yield was observed at the $17.841 \mu \mathrm{M}$ concentration of cerium, which was $23.91 \%, 67.53 \%$ for shoot and root length and $178.08 \%, 207.14 \%$ for shoot and root relative yield, respectively, over the control. Beyond this concentration, a gradual decrease in the shoot-root length and relative yield was observed. Retardation in growth was observed at higher concentrations of cerium ( 89.206 and $446.030 \mu \mathrm{M})$. The maximum decrease in shoot-root length and relative yield $(26.08 \%$, $49.31 \%$ for shoot and root length; $44.94 \%, 53.57 \%$ for shoot and root relative yield, respectively, over the control) was observed at the $446.030 \mu \mathrm{M}$ dose of cerium. At the $446.030 \mu \mathrm{M}$ cerium level, the root growth was drastically affected, and this concentration was proved to be highly toxic for cowpea plants. Diatloff et al. (1999) also found that $0.03-0.7 \mathrm{mg} / \mathrm{L} \mathrm{La}$ or Ce reduced growth and the uptake rate of all nutrients for mungbeans and that $0.7 \mathrm{mg} / \mathrm{l} \mathrm{La}$ or Ce had little effect on growth but reduced the uptake of $\mathrm{Ca}$ for corn. 
Table 2. Showing the effect of various concentrations of cerium provided as cerium nitrate on shoot-root length and shoot-root relative yield of Vigna unguiculata (L.) Walp.

\begin{tabular}{|c|c|c|c|c|}
\hline $\begin{array}{l}\text { Cerium } \\
\text { Concentrations } \\
(\mu \mathrm{M})\end{array}$ & Shoot length $(\mathrm{cm})$ & Root length $(\mathrm{cm})$ & $\begin{array}{l}\text { Shoot relative } \\
\text { yield }(\%)\end{array}$ & Root relative yield (\%) \\
\hline 0.000 & $27.60 \pm 1.110$ & $7.30 \pm 0.294$ & $100.00 \pm 0.000$ & $100.00 \pm 0.000$ \\
\hline 0.713 & $29.10 \pm 1.309$ & $8.80 \pm 0.396$ & $130.89 \pm 5.890$ & $125.00 \pm 5.625$ \\
\hline 3.568 & $31.90 \pm 0.957$ & $10.20 \pm 0.306$ & $150.00 \pm 4.500$ & $164.28 \pm 4.928$ \\
\hline 17.841 & $34.20 \pm 0.592$ & $12.20 \pm 0.211$ & $178.08 \pm 3.084$ & $207.14 \pm 3.588$ \\
\hline 89.206 & $24.90 \pm 0.470$ & $4.50 \pm 0.085$ & $60.67 \pm 1.145$ & $92.85 \pm 1.753$ \\
\hline 446.030 & $20.40 \pm 0.385$ & $3.70 \pm 0.070$ & $44.94 \pm 0.848$ & $53.57 \pm 1.011$ \\
\hline LSD & 0.4789 & 0.1359 & 1.8365 & 1.9361 \\
\hline $\begin{array}{l}\mathrm{CD}(\mathrm{P}=0.05)(\mathrm{CD} \\
\text { at } 5 \%)\end{array}$ & 1.4757 & 0.4186 & 5.6589 & 5.9656 \\
\hline $\begin{array}{l}\mathrm{CD}(\mathrm{P}=0.01)(\mathrm{CD} \\
\text { at } 1 \%)\end{array}$ & 2.0688 & 0.5868 & 7.9334 & 8.3633 \\
\hline $\mathrm{CV}(\%)$ & 2.96 & 3.02 & 2.87 & 2.71 \\
\hline General mean & 28.017 & 7.783 & 110.763 & 123.807 \\
\hline $\mathrm{r}$ & -0.8139 & -0.7000 & -0.7106 & -0.6712 \\
\hline$r^{2}$ & 0.663 & 0.4900 & 0.5049 & 0.4505 \\
\hline$y=a+b x$ & $\begin{array}{l}30.13816^{* *} *_{-} \\
0.02284 * \mathrm{x}\end{array}$ & $\begin{array}{l}9.02418 * *_{-} \\
0.01309 *^{x}\end{array}$ & $\begin{array}{l}130.16714^{* *} *_{-} \\
0.20888^{* *} \mathrm{x}\end{array}$ & $\begin{array}{l}143.20134 * *_{-} \\
0.20879 * *^{x}\end{array}$ \\
\hline
\end{tabular}

$*=$ Significant at $5 \%$ level of significance.

$* *=$ Significant at $1 \%$ level of significance. 


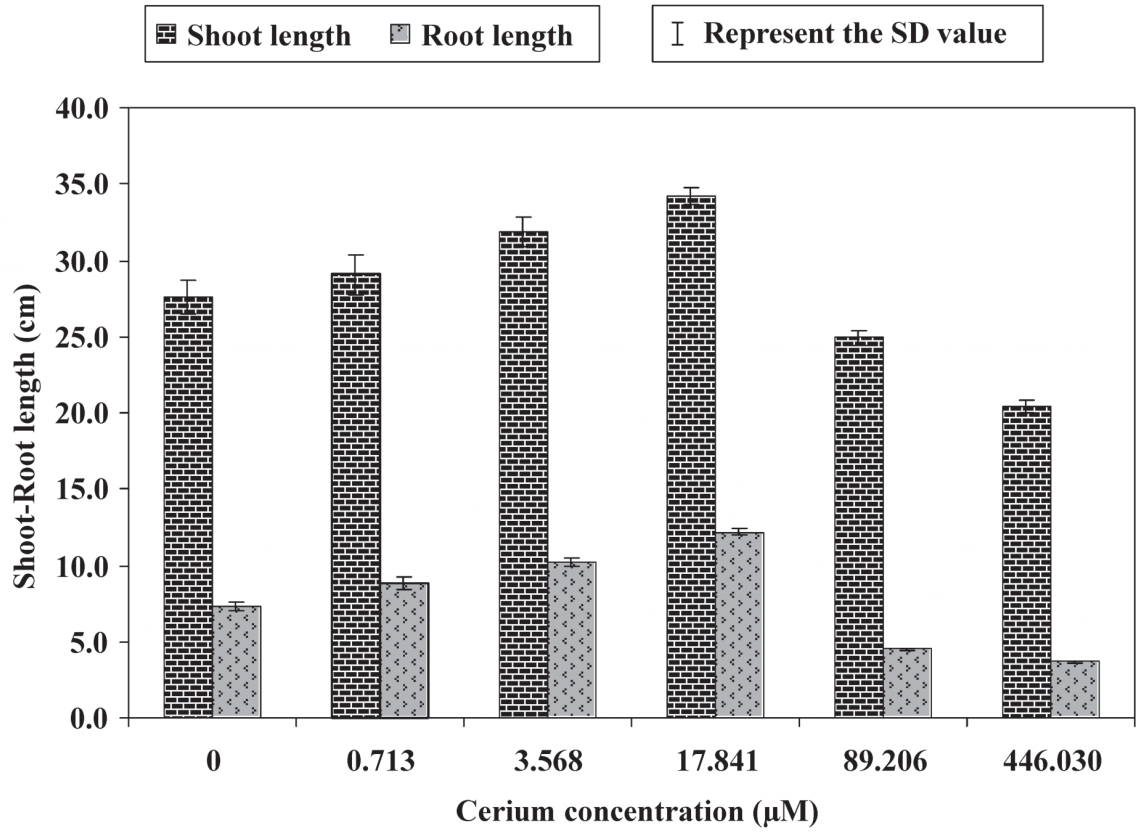

Figure 5. The effect of various concentrations of cerium on the shoot-root length (cm) of Vigna unguiculata (L.) Walp.

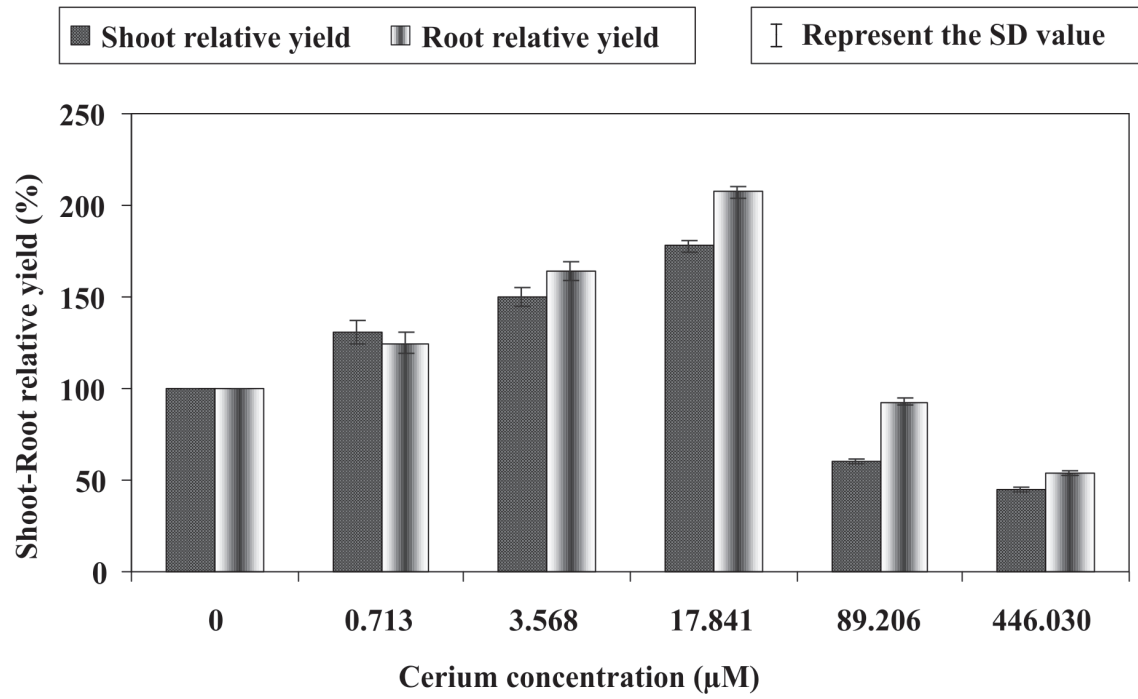

Figure 6. The effect of various concentrations of cerium on the shoot-root relative yield of Vigna unguiculata (L.) Walp. 
Growth inhibition caused by cerium can be attributed to the loss of cellular turgor (Gabbrielli et al., 1990) or to a reduced extensibility of the cell wall (Pandolfini et al., 1992; Aery and Jagetiya 1997; Mali and Aery, 2009), or it might be due to a decreasing efficiency of certain enzymes involved in food and energy utilisation. d'Aquino et al. (2009) has attributed the reduction in root growth after the treatment of REEs to a decrease in cell division.

\section{Conclusion}

Cerium is not essential for crop plants, but the present study indicates that low levels of cerium enhance the shoot-root growth and relative yield (dry matter production), and cerium is beneficial for cowpea plants. Higher levels of cerium decrease plant growth and relative yield. Applied cerium concentrations showed a significant positive correlation with the proline content and polyphenol oxidase activity and a negative correlation with the foliar chlorophyll content, nitrate reductase activity, shoot-root length and relative yield. The probable role of cerium as a substitute for $\mathrm{Mg}^{2+}$ in chlorophyll synthesis is indicated.

\section{Acknowledgements}

The authors are thankful to UGC, New Delhi, for providing financial assistance in the form of a meritorious fellowship to Radhe Shyam.

\section{References}

Aery, N. C., Jagetiya, B. L. 1997. Relative toxicity of cadmium, lead and zinc on barley. Commun. Soil Sci. Plant Anal. 28 (11\& 12), 949-960.

Arnon, D. I. 1949. Copper enzyme in isolated chloroplast: Polyphenol oxidase in Beta vulgaris L. Plant Physiol. 24, 1-15.
Awasthi, M. 2005. Nitrate reductase activity: A solution to nitrate problems tested in free and immobilized algal cells in presence of heavy metals. Int. J. Environ. Sci. Tech. 2(3), 201-206.

Bates, L. S., Waldren, R. P., Teare, I. D. 1973. Rapid determination of free proline for water stress studies. Plant and Soil 39, 205-207.

Beevers, L., Hageman, R. H. 1969. Nitrate reduction in higher plants. Annu. Rev. Plant Physiol. 20, 495-522.

d'Aquino, L., de Pinto, M. C., Nardi, L., Morgana, M., Tommasi, F. 2009. Effect of some light rare earth elements on seed germination, seedling growth and antioxidant metabolism in Triticum durum. Chemosphere 75, 900-905.

Del Rio, L. A. 1983. Metalloenzyme as biological markers for the appraisal of micronutrient imbalances in higher plants. Life Chemistry Reports 1, $1-33$.

Diatloff, E., Asher, C. J., Smith, F. W. 1999. The effects of rare earth elements on the growth and nutrition of plants. Rare earths' 98, Materials Science Forum 315(3), 354-360.

Fisher, R.A. 1950. Statistical methods for research workers. Oliver and Boyd. Edinburg, London, $354 \mathrm{p}$.

Gabbrielli, R., Pandolfini, T., Vergnano, O., Palandri, M. R. 1990. Comparison of two serpentine species with different nickel tolerance strategies. Plant and Soil 122(2), 271-277.

Guerrero, MG., Vega J., Losada M. 1981. The assimilatory nitrate- reducing system and its regulation. Annu. Rev. Plant Physiol. 32, 169-204.

Guo, B. S, Zhu, W. M., Xiong, P. K., Ji, Y. J., Liu, Z., Wu, Z. M. 1988. Rare earths elements in agriculture. Agricultural Scientific Technological Press, Beijing: 23-208 (In Chinese). 
Hassan Ragab Hassan El. Ramady. 2008. A contribution on the bio-actions of rare earth elements in the soil/ plant environment. Ph.D. Thesis, TUBraunschweig, $173 \mathrm{p}$.

He, Y. W., Loh, C. S. 2000. Cerium and lanthanum promote floral initiation and reproductive growth of Arabidopsis thaliana. Plant Sci.159, 117-124.

Hong, F. S., Wie, Z.G., Zhao, G. W. 2002. Mechanism of lanthanum effect on the chlorophyll of spinach. J. Science in China, Series C, 45 (2), 166-176.

Hu, Q. H., Ye, Z. J. 1996. Physiological effects of rare earth elements on plants. Chin. Plant Physiol. Commun. 32(4), 296-300.

Jie, H. G., Yu, Z. H. 1985. Effects of REEs on increasing yield and physiology of wheat. J. Heilongjiang Agric. Sci. 1, 25-29.

Ketchum, R. E. B., Warren, R. C., Klima, L. J., Lopez -Gutierrez, F., Nabors, M. W. 1991. The mechanism and regulation of proline accumulation in suspension cultures of the halophytic grass Distichlis spicata L. J. Plant Physiol. 137, 368-374.

Lehoczky, E., Marth, P., Szabados, I., Szomolanyi, A. 2000. The cadmium uptake by lettuce on contaminated soils as influenced by liming. Commun. Soil Sci. Plant Anal. 31, 2433-2438.

Li Guo-tai. 2010. Effect of cerium on chilling resistance of cucumber seedlings. Northern Horticulture 16, 47-48.

Li, J. M., Liang, C. J, Zhou, Q. 2007. Effect of cerium on photosynthesis in young soybean plants. Chinese J. Oil Crop Sci. 29(1), 90-92. (In Chinese)

Liao, T. J., Huang, Y., Su, L. B. 1994. Study of rare earths on yields, qualities and physiological effect of Spinach. Rare Earths 15, 26-29 (In Chinese).
Mahadevan, A., Sridhar, R. 1982. Methods in physiological plant pathology. Siva Kami Publication, Madras, $316 \mathrm{p}$.

Mali, M., Aery, N. C. 2009. Effect of silicon on growth, biochemical constituents and mineral nutrition of cowpea (Vigna unguiculata (L.) Walp.). Commun. Soil Sci. Plant Anal. 40, 1041-1052.

Malik C. P., Singh, M. B. 1980. Plant enzymology and histoenzymology. Kalyani Publishers, New Delhi, India, $433 \mathrm{p}$.

Michalak, A. 2006. Phenolic compounds and their antioxidant activity in plants growing under heavy metal stress. Polish J. of Environ. Stud. 15(4), 523-530.

Ni, J. Z. 1995. The use of rare earth elements in agriculture and medicine. In: Bioinorganic Chemistry of Rare Earth Elements. Science Press, Beijing, China, pp: 13-55.

Pandolfini, T., Gabbrielli, R., Comparini, C. 1992. Nickel toxicity and peroxidase activity in seedlings of Triticum aestivum L. Plant Cell Environ. 15, 719-725.

Panse, V.G. and Sukhatme, P.V. 1995. Statistical methods for agricultural works. Indian Council of Agricultural Research, New Delhi, 330p.

Pillinger, J. M., Cooper, J. A., Ridge, I. 1994. Role of phenolic compounds in the antialgal activity of barley straw. J. Chem. Ecol. 20(7), 1557-1569.

Pilon-Smits, EAH, Quinn, CF, Tapken, W., Malagoli, M., Schiavon, M. 2009. Physiological functions of beneficial elements. Current Opinion in Plant Biology 12, 267-274.

Robby, D. A., Mapson, L. W., Swain, T. 1964. Activation of the latent tyrosinase of broad bean. Nature 201, 503-504. 
Shyam, R., Aery, N. C. 2011. Effect of cerium on seed germination and early seedling growth of wheat. NBU J Plant Sc. 5, 51-55.

Somashekaraiah, B. V., Padmaja, K., Prasad, A. R. K. 1992. Phytotoxicity of cadmium ions on germinating seedlings of mung bean (Phaseolus vulgaris): involvement of lipid peroxides in chlorophyll degradation. Physiologia Plantarum 85(1), 85-89.
Wang, X., Shi, G. X., Xu, Q. S., Xu, B. J, Zhao, J. 2007. Lanthanum and cerium induced oxidative stress in submerged Hydrilla verticillata plants. Russ. J. Plant Physiol. 54, 693-697.

Yin, S., Ze, Y., Liu, C., Li, N., Zhou, M., Duan, Y., Hong, F. 2009. Cerium relieves the inhibition of nitrogen metabolism of spinach caused by magnesium deficiency. Biol. Trace Elem. Res. 132, 247-258. 